\title{
人工内耳患者における合成母音検査
}

\author{
東京医科大学耳鼻咽喉科学教室 (主任: 船坂宗太郎教授) \\ 斎藤啓光, 博 久詠司, 渡辺一雄, 湯川 久美子 \\ 佐 藤 恒 正, 船 坂 宗太郎
}

\section{TESTING OF SYNTHETIC VOWELS IN PATIENTS WITH 22 CHANNEL COCHLEAR IMPLANT}

\author{
HIROMITSU SAITO, M.D., EIJI HAKUHISA, M.D., Kazuo Watanabe, M.D. \\ KUMIKO YUKAWA, M.D., TSUNEMASA SATO, M.D. \\ and SOTARO FUNASAKA, M.D.
}

Department of Otorhinolaryngology, Tokyo Medical College, Tokyo

In the 22 multi-channel cochlear implant system, $\mathbf{F}_{0}$ information determines the frequency of electrical stimulation, and $F_{1}$ and $F_{2}$ information determine the number of stimulating electrodes. We performed tests using synthetic vowels on 16 patients who had undergone 22 channel cochlear implant surgery and 6 months' speech rehabilitation. Information transmission rates were calcu. lated to analyze the response pattern. As a result, 1) the vowel recognition ability of patients with cochlear implant surgery correlated with the number of electrodes being used. 2) The value of vowel confusion decreased so as to be separated by a pair of stimulating electrodes, and the confusion in $F_{1}$ information was regarded to be less than that for $F_{2}$ information.

Key words : 人工内耳, 合成母音, 情報伝送量, 母音聴取率

A $97-2065-23582$

\section{1.はじめに}

現在我々の使用しているオーストラリア製22チャン ネル人工内耳では，母音については基本周波数 $\mathrm{F}_{0}$ に より刺激電気パルスの頻度を，そして，第 1 および第 2 ホルマントすなわち, $\mathrm{F}_{1}, \mathrm{~F}_{2}$ により，刺激電極を設 定している。刺激電極の設定はMAPにより，先端部 より0〜 4000Hzまでの間の各周波数带に応じた電極 を選択する仕組みになっている，電極束の長さは $17 \mathrm{~mm}$ で, $0.75 \mathrm{~mm}$ 間隔に電極が位置し, 22本の電極 すべて括入された場合でも，正常蝸牛に打ける 20000 $\sim 1000 \mathrm{~Hz}$ 付近に相当する部位を刺激しているにすぎ ない1，つまり，人工内耳は MAP と称されるプログラ ムにより，音声をあらかじめ定められた周波数带域に 分類して刺激部位を定め，基本周波数の電気パルス頻 度て，蝸牛の中，高音部を刺激するという音の伝達様

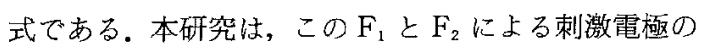
設定と, 言葉の栮き取りの関係の追求を目的としたも のである。

従来の肉声による母音恥取率では，異恥傾向は推測 できるものの， $\mathrm{F}_{1}, \mathrm{~F}_{2}$ の情報が言葉の聞き取りにどの ように関与しているかは不明であった。しかし，今回 合成母音検查を人工内耳恵者に行うことにより，ホル マントごとの解析が可能となった。また，音䫓情報の 伝達能力を表現するものとして情報伝送量を計算し， 使用電極数との関係, 従来の肉声による母音聴取率と の関係について検討を行った。また，電極間距離と $F_{1}$ での異聴傾向, $F_{2}$ での異聴傾向， $F_{1} と F_{2}$ を合わせた 場合 $\left(\mathrm{F}_{1}+\mathrm{F}_{2}\right)$ での異聴傾向についての分析も合わせ て行い，若干の知見が得られたので報告する。 
合成母音検查 (正常例)

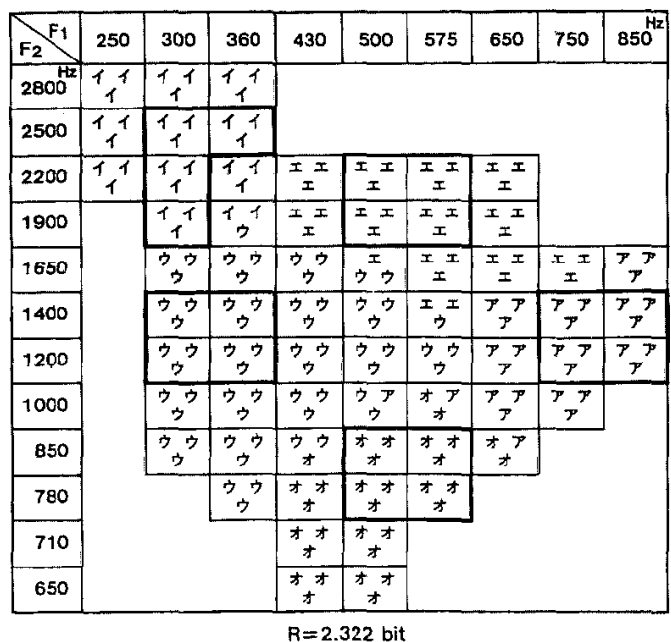

情報伝送量

$R=\sum_{j}\left\{(-Q j \log Q i)-\left(-P j \sum_{i} p i j \log p i j\right)\right\}$

pijは母音ViをVjと閶く確率

$P j$ 油母音 $V j$ の呈示准率

$\mathrm{Qj}=\sum_{\mathrm{i}} \mathrm{Pi} \cdot \mathrm{pij}$ は音 $V j$ 聴取確率

図 1 合成母音検查の正常例と情報伝送量

$F_{z}$ 抢よび $F_{2}$ の組み合わせにより作製した64個の合成母音 の, 典型的正常パターンを図左に示す. 基本周波数 $\mathrm{F}_{0}$ は固定 し, $\mathrm{F}_{1}$ および $\mathrm{F}_{2}$ ホルマントに相当する周波数帯域を变数と して選択し，この組み合わせを聴くことによって $\mathrm{F}_{1}-\mathrm{F}_{2}$ パ ターンが作られる。なお，図の太線で囲ったところは，95\% 信頼区間を示し，これより情報伝送量を計算すると，正常で は2.322bitとなる。

\section{2. 対象および検查方法}

人工内耳の手術後 6 力月以上経過し，リハビリも終 了して安定している患者16名（12～74歳）に検查を施 行した。検查用合成母音は東京大学工学部藤崎研究室 に扔けるターミナル・アナログ型音声合成器を用いて 合成したもので，詳細は富澤りの報告による．図１に， 合成母音検査の正常例と情報伝送量の算出法を示す。 図1の太線で囲ったところは，95\%信頼区間を示し， これより情報伝送量を計算すると, 正常では 2.322bit となる。

\section{3. 結 果}

表 1 k人工内耳患者 16 例の電極数，母音聴取率，情 報云送量を示す．電極数は手術時に㨉入可能であった 電極数ではなく, 術後 6 力月目に実際に使用していた 電極数を示す.母音聴取率は肉声によるもので, 2 回 もしくは 3 回施行した平均值を示す。また, 情報伝送 量は合成母音聴取検查結果加らの情報伝送量であり, 当然, 肉声による母音聴取検査時と同じ MAP を使用
して算出した值である。図 2 に電極数と合成母音情報 伝送量との関係を示す. 電極数汇順序尺度 (RANK) により,変数変換を行っている. 相関係数は 0.792 と高 い数值をし， $1 \%$ 有意水準で相関関係が認められ $た(>0.6226)$. 図 3 に母音聴取率と合成母音情報伝送 量との関係を示す. 相関係数は0.861とさらに高い数 值を示した。

次に，患者個々のMAP より，おのおのの合成母音 がどの電極を刺激しているかを計算した，合成母音の 異聴率は， $\mathrm{F}_{1}$ のみ， $\mathrm{F}_{2}$ のみ，そして， $\mathrm{F}_{1}, \mathrm{~F}_{2}$ の両者 $\left(\mathrm{F}_{1}+\mathrm{F}_{2}\right.$ と記す) を考慮した 3 通りの異聴率検討を行 った，通常，電極の刺激法としては，1本おきに隣り 合った電極を対として刺澈する電極そード $(\mathrm{BP}+1)$ が 採用される。例光ば症例13では(図 4)，挿入電極数は 20 本で，刺激する電極モ一ドは BP+1であるので, 18 通りの刺激法が考えられる。また，㨉入電極は最も螖 牛空寄りの電極から 1 番と称され，抽出された最も高 い周波数帯（最高は $4000 \mathrm{~Hz}$ まで）を担当する．以後， 頂回転側に進むにつれて，2 番，3番と順次番号をつ 
表 1 人口内耳患者16例の電極数，母音聴取率，情報 伝送量

\begin{tabular}{|c|c|c|c|}
\hline $\begin{array}{c}\text { 症例 } \\
\text { No. }\end{array}$ & $\begin{array}{c}\text { 電極数 } \\
\text { (本) }\end{array}$ & $\begin{array}{c}\text { 母音聴取率 } \\
\text { (\%) }\end{array}$ & $\begin{array}{c}\text { 情報伝送量 } \\
\text { (bit) }\end{array}$ \\
\hline 1 & 11 & 25 & 0.315 \\
\hline 2 & 11 & 55 & 1.156 \\
\hline 3 & 12 & 40 & 0.518 \\
\hline 4 & 15 & 73 & 1.109 \\
\hline 5 & 16 & 53 & 1.127 \\
\hline 6 & 16 & 70 & 0.854 \\
\hline 7 & 17 & 35 & 0.432 \\
\hline 8 & 19 & 73 & 1.255 \\
\hline 9 & 19 & 97 & 1.936 \\
\hline 10 & 19 & 79 & 1.241 \\
\hline 11 & 19 & 93 & 1.264 \\
\hline 12 & 19 & 90 & 1.371 \\
\hline 13 & 20 & 85 & 1.552 \\
\hline 14 & 21 & 70 & 1.586 \\
\hline 15 & 22 & 73 & 1.665 \\
\hline 16 & 22 & 95 & 1.695 \\
\hline
\end{tabular}

け，次第に低い周波数帯に移行する。つまり，症例13 の場合では $\mathrm{BP}+1$ のードのため, electrode 1 番と 3 番の刺激電極対が最も高い周波数帯を担当する刺激 電極となる，逆に，electrode18番と20番の刺激電極対 が最も低い周波数帯を担当する刺激電極対である。つ まり，図 4 の MAPに示された electrode 20 の担当周 波数は 0 400Hz, electrode 19 は 401〜 $520 \mathrm{~Hz}$ までを 担当していることを示している。この MAPょり，理 論上計算される担当周波数帯を合成母音の $\mathrm{F}_{1}, \mathrm{~F}_{2}$ 構 成周波数に当てはめ，おのおのの合成母音が, $F_{1}$ と $F_{2}$ でそれぞれどの電極対を刺激しているかを決定した。 図 4 の合成母音検查結果の表で，（）に示された番号 が理論上算定された刺激電極対である。

まず， $F_{1}$ に関して言えば，イとウについては電極に 蒫がないことになり（この場合 $\mathrm{F}_{2}$ は考慮にいれてい ない)，イとウのどちらを答えた場合でも正解，エ、ア， オと答えた場合を不正解とした。 その場合，電極の差 は，工，才の場合が 1 電極，アの場合が 3 電極異なる ことになる、エとオについても同様である、また、ア

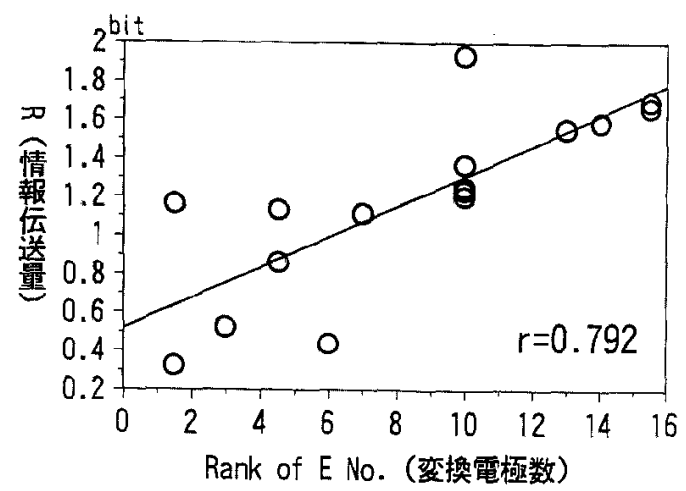

図 2 電極数と合成母音情報伝送量との関係 電極数は順序尺度 (RANK)により，変 数変換を行っている. 相関係数は 0.792 で，1\%の有意水準で相関関係があると 竐六た $(>0.6226)$.

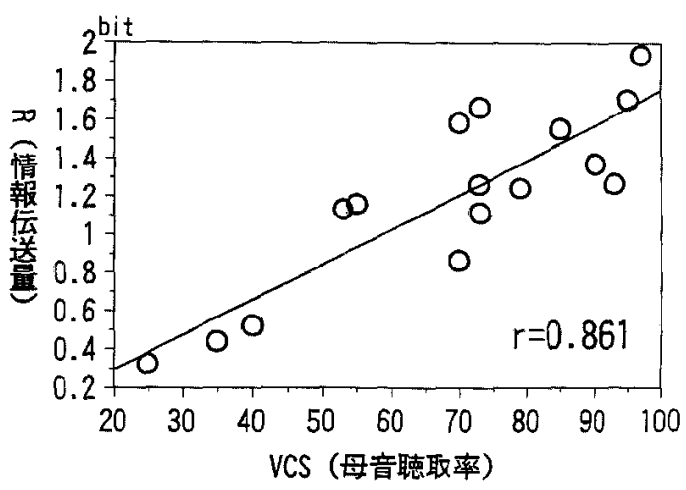

図 3 母音聴取率と合成母音情報伝送量と0)関 係

相関傒数は $0.861 て ゙, 1 \% の$ 有意水準で相 関関係があると言光た（>0.6226）。

はアと答えた場合のみ正解で，イ，エ，才，ウと答え た場合は不正解となる，その場合，イ，とウとは 3 電 極，工，オとは 1 電極異なることになる． $\mathrm{F}_{2}$ に関して も同様であり、イとエについて，イとエのどちらを答 えた場合でも正解，ウ，ア，才と答えた場合を不正解 とした.電極の差は,ウ,アの場合が $1400 \mathrm{~Hz}$ と $1900 \mathrm{~Hz}$ の間で 3 電極，才の場合䚮 7 電極異なることになる。 ウとアの場合，才の場合も同様に計算した。次に， $F_{1}+$ $\mathrm{F}_{2}$ では，イはイと答えた場合のみを正解，それ以外は 不正解とし，エとは $\mathrm{F}_{1}$ のみで 1 電極，アとは $\mathrm{F}_{1}$ で 3 電極, $\mathrm{F}_{2}$ で 3 電極異なるために, 合計で 6 電極異なる ことになる。オとは $F_{1} て ゙ 1$ 電極, $F_{2}$ で 7 電極, 合計で 


$\begin{array}{cc}\text { Elect. } & \text { Upper Freq. Bounds } \\ 20 & 400 \\ 19 & 520 \\ 18 & 640 \\ 17 & 760 \\ 16 & 880 \\ 15 & 1000 \\ 14 & 1122 \\ 13 & 1259 \\ 12 & 1414 \\ 11 & 1587 \\ 10 & 1781 \\ 9 & 2000 \\ 8 & 2244 \\ 7 & 2519 \\ 6 & 2828 \\ 5 & 3174 \\ 4 & 3563 \\ 3 & 4000\end{array}$

\begin{tabular}{|c|c|c|c|c|c|c|c|c|c|c|}
\hline \multirow{2}{*}{ 坦当 } & \multirow{2}{*}{ F2 } & \multicolumn{3}{|c|}{ (20) } & \multicolumn{2}{|c|}{ (19) } & \multirow{2}{*}{$\begin{array}{l}\text { (18) } \\
575 \\
\end{array}$} & \multicolumn{2}{|c|}{ (17) } & \multirow{2}{*}{\begin{tabular}{|c|}
$(16)$ \\
$850^{\text {Hz }}$ \\
\end{tabular}} \\
\hline & & 250 & 300 & 360 & 430 & 500 & & 650 & 750 & \\
\hline (6) & $2800^{\mathrm{Hz}}$ & $1_{1}$ & 24 & $I_{I}$ & & & & & & \\
\hline (7) & 2500 & $1_{1}$ & 11 & $1 \pm$ & & & & & & \\
\hline (8) & 2200 & 19 & $7_{7}$ & $1_{x} x$ & $\begin{array}{c}{ }_{2} \\
I\end{array}$ & \begin{tabular}{|l|}
$I$ \\
\end{tabular} & $\begin{array}{c}x \\
x\end{array}$ & II & & \\
\hline (9) & 1900 & & ウウ & $I_{0} x$ & $\begin{array}{c}I I \\
I\end{array}$ & \begin{tabular}{|c|} 
\pm \\
\pm
\end{tabular} & $\begin{array}{c}x \\
x\end{array}$ & $\begin{array}{c}x I \\
I\end{array}$ & & \\
\hline (10) & 1650 & & $\begin{array}{c}{ }^{2} \overrightarrow{ } \\
\Rightarrow\end{array}$ & $\begin{array}{c}{ }_{2} \\
\Rightarrow\end{array}$ & $7 x$ & $\begin{array}{c}I^{I} \\
\end{array}$ & $\begin{array}{c}\pi \\
7\end{array}$ & $\begin{array}{c}77 \\
7 \\
\end{array}$ & $\begin{array}{c}77 \\
7 \\
\end{array}$ & $\begin{array}{c}77 \\
7\end{array}$ \\
\hline (12) & 1400 & & ウ" & 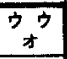 & $\begin{array}{c}{ }^{2} x \\
x\end{array}$ & $\begin{array}{c}T \\
\pi\end{array}$ & ${ }^{\pi}{ }^{\pi}$ & $\pi x$ & $\begin{array}{c}77 \\
7\end{array}$ & $\begin{array}{c}7 \\
P\end{array}$ \\
\hline (13) & 1200 & & म" & न & $\pi$ & ${ }_{\pi}{ }_{\pi}$ & ${ }_{\pi}^{*}$ & ${ }^{\pi} 7$ & $\begin{array}{c}77 \\
7\end{array}$ & $\begin{array}{c}77 \\
7\end{array}$ \\
\hline (15) & 1000 & & ウウ & $\dot{\pi}^{\star}$ & 万" & ${ }_{7}^{7}$ & $\begin{array}{l}\pi \\
\pi\end{array}$ & $\begin{array}{r}7 \% \\
7 \\
\end{array}$ & $\begin{array}{c}7 \pi \\
7\end{array}$ & \\
\hline \multirow{2}{*}{ (16) } & 850 & & $\nabla_{\nabla}$ & $\vec{n}^{\prime}$ & $\begin{array}{c}\pi \\
0\end{array}$ & \begin{tabular}{|c|}
$7{ }^{*}$ \\
\end{tabular} & $\begin{array}{c}77 \\
7\end{array}$ & $\begin{array}{c}7 \pi \\
t\end{array}$ & & \\
\hline & 780 & & & $i^{\pi}$ & $\begin{array}{c}t \\
0\end{array}$ & $\begin{array}{c}7 \\
\pi \\
\end{array}$ & $\pi$ & & & \\
\hline \multirow{2}{*}{ (17) } & 710 & & & & $\begin{array}{r}\eta^{\prime} \\
\Rightarrow\end{array}$ & ${ }^{\pi} \pi$ & & & & \\
\hline & 650 & & & & $\begin{array}{c}\pi \\
\pi\end{array}$ & $\begin{array}{c}\pi \\
\pi\end{array}$ & & & & \\
\hline
\end{tabular}

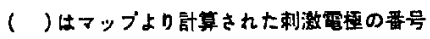

図 4 症例130マップと合成母音検査結果

㨀入電極数は20本で, 刺激電極モードは $\mathrm{BP}+1$ が採用されている. 合成 母音 $\mathrm{F}_{1}, \mathrm{~F}_{2}$ の周波数が, 実際にどの電極を刺激しているかをマップより 計算し, 刺激電極対の担当電極番号を（）に示した。

表 $2 \quad \mathrm{~F}_{1}, \mathrm{~F}_{2}, \mathrm{~F}_{1}+\mathrm{F}_{2}$ での異聴率

16例の平均值と標準偏差を示す. $\mathrm{F}_{1}, \mathrm{~F}_{2}, \mathrm{~F}_{1}+\mathrm{F}_{2}$ において, 電極間 距離が異なるほど異聴率が減少している.さらに, $\mathrm{F}_{2}$ よりも $\mathrm{F}_{1}$ での

異聴がより少ない傾向が認められた。

\begin{tabular}{|c|c|c|c|c|}
\hline \multirow{2}{*}{ 電極間の差 } & \multicolumn{4}{|c|}{$F_{1}$} \\
\cline { 2 - 5 } & 1 & 2 & 3 & 4 \\
\hline $\begin{array}{l}\text { 16例の平均値 } \\
\text { と標準偏差 }\end{array}$ & $19.2 \pm 8.8$ & $12.3 \pm 8.0$ & $2.8 \pm 2.6$ & 0 \\
\hline
\end{tabular}

\begin{tabular}{|c|c|c|c|c|}
\hline \multirow{2}{*}{ 電極間の差 } & \multicolumn{4}{|c|}{$\mathrm{F}_{2}$} \\
\cline { 2 - 5 } & 1 & 2 & 3 & $4 \sim 8$ \\
\hline $\begin{array}{c}\text { 16例の平均值 } \\
\text { と標準偏差 }\end{array}$ & $22.2 \pm 11.3$ & $20.6 \pm 13.7$ & $15.6 \pm 7.5$ & $5.3 \pm 9.5$ \\
\hline
\end{tabular}

\begin{tabular}{|c|c|c|c|c|c|c|c|c|}
\hline \multirow{2}{*}{ 電極間の差 } & \multicolumn{7}{|c|}{$F_{1}+F_{2}$} \\
\cline { 2 - 9 } & 1 & 2 & 3 & 4 & 5 & 6 & 7 & $8 \sim 9$ \\
\hline $\begin{array}{c}\text { 16例の平均值 } \\
\text { と標準偏差 }\end{array}$ & $13.7 \pm 8.3$ & $12.9 \pm 9.1$ & $9.2 \pm 5.3$ & $9.9 \pm 7.3$ & $6.3 \pm 11.2$ & $4.9 \pm 5.9$ & $2.2 \pm 6.7$ & $0.5 \pm 1.3$ \\
\hline
\end{tabular}


8 電極, ウとは $\mathrm{F}_{2}$ のみで 3 電極異なることになる.以 下，エ，ア，才，ウも同様に計算した。

以上より $\mathrm{F}_{1}, \mathrm{~F}_{2}, \mathrm{~F}_{1}+\mathrm{F}_{2}$ での異聴率を16例について 計算し，その平均値と標準偏差を算出した(表 2)。 ま ず， $\mathrm{F}_{1}$ では電極が異なるほど, 異聴が少なくなり，4 電極異なる場合では異聴率が 0 となった $\mathrm{F}_{2}$ でもやは ク，電極が異なるほど異聴が少なくなったが，4電極 以上異なる場合でも異聴が認められた。つまり， $\mathrm{F}_{1}$ ， $\mathrm{F}_{2}$ ともに担当する電極問距離が異なるほど, 異聴率が 低くなる傾向が認められ，さらに $\mathrm{F}_{2}$ よりも $\mathrm{F}_{1}$ での暴 聴がより少ない傾向が認められた。 また, $\mathrm{F}_{1}+\mathrm{F}_{2}$ でも， 電極が異なるにつれて異聴率は低くなり，最低 6 電極 以上離すことができれば $5 \%$ 以下の低い異聴率が得ら れることがわかった。

\section{4. 考 察}

従来より,人工内耳患者の評価法として, 母音聴取 能, 子音聴取能, 単語や文節による評価法がなされて いるが3445), これらはすべて肉声によるものであった。 人工内耳は当然のこととして，主に人の会話を聞き取 ることを第一の目的として造られたものであり，これ らの評価法は重要なことは言うまでもない。しかし， 今回我々の検討は，人工的に造り上げた音声つまり合 成母音を使用することにより, 蝸牛を常に一定部位別 に電気刺激することで, 音声処理と聴取率との間にど のような関係があるか, 基礎的に解明できる手掛かり になるものである，以前著者は，モルモットを用いた 電気生理学的実験で, 蝸牛を部位別に電気刺激するこ とにより, EABR を指標として検討し情報が異なる示 唆を得て報告しだ。. 今回, 実際に人工内耳装着した 㭧者で合成母音を使用することは，臨床面に扔いても このことを証明する良い方法と考える。

まず，検査用合成母音であるが，これを新たに作製 した場合には, 正常者や難聴者においてあらかじめ検 討を行う必要がある.このため, 正常者, 感音難聴者, 後迷路性難聴者などで前もって検討がなされ2)7，しか も，現在臨床的にも用いられているものを採用した。 都合のよいことに, $\mathrm{F}_{0}, \mathrm{~F}_{3}, \mathrm{~F}_{4}$ は固定されてお括り， $\mathrm{F}_{1}$ と $\mathrm{F}_{2}$ のみを変化させることにより，合成母音を作製 している。今回， $\mathrm{F}_{1} ， \mathrm{~F}_{2}$ の情報が言枼の聞き取りに， どのように関与しているかを検討する手段としては， きわめて適した娭查法と考えられる。また，図10合 成母音検査表の中で，太線で囲ったところは95\%信頼 区間を示しており，この太線で囲ったところから情報
伝送量や， $F_{1}, F_{2}$ ての異聴率を算出している。異聴率 の算出にあたっては， $F_{1}$ と $F_{2}$ とで別々に検討を行っ ているが，両者の異聴率を比較する上で，条件が同等 でなければならない. 例えば， $\mathrm{F}_{1}$ ではイとウ，エと才 がそれぞれ正答する確率は2/5ずつであり,アの場合は 1/5である.一方 $\mathrm{F}_{2}$ でも，イとエ，ウとアが正答する 確率は2/5ずつであり，才の場合は $1 / 5$ 5 あ゙る。つまり， $\mathrm{F}_{1}$ と $\mathrm{F}_{2}$ ともに条件は同等であり，この合成母音検査 法は $\mathrm{F}_{1}$ と $\mathrm{F}_{2}$ との情報量の違いを比較する上でも, 適 したものと考えられる。

次に症例に関してであるが, 症例は, 人工内耳手術 後 6 力月以上経過し,リハビリが終了して, 人工内耳 を日常生活で使用している患者を選んだ．MAPは当 然のことながら，肉声による母音聴取率と同じ MAP を使用して合成母音検查を行っており，日常使用して いるMAPである，つまり，電極数の少ない患者は， 手術時に22本すべて挿入できなかった患者であり，22 本入った息者见，本数を減らして検査を行っているわ けではない。これは当然のことながら，普段22本使用 している患者に, 突然本数を減らして検査を行っても， 検査結果は当然悪くなるはずだからである。

まず今回，合成母音検査結果より得られる情報伝送 量が, 㨉入電極数や, 従来の肉声による母音聴取率と, どのような相関があるかについて検討を行った．以前 城間らは ${ }^{8) 9}$, 㨉入電極数と母音聴取率とは相関を示し たとの報告を行っている，今回，情報伝送量が，㨉入 電極数や肉声による母音聴取率と，1\%の有意水準を もって相関を認めた。つまり，基底板上のより多くの 異なる部位を電気刺激することで，より多くの正碓な 情報を送り得ること, そして, 蝸牛の電気刺激でも複 数部位を局所刺激することで, spacious pattern とし て，より多くの音声情報を送り込んでいることが証明 された. また，今後合成母音検查法が人工内耳患者の 評価法としても，利用できる可能性が示唆されたもの と考える.なお，今回の㮩查結果でも，挿入電極数と 肉声による母音聴取率とは, 相関係数 0.726 と高い数値 を示した。

情報伝送量は，音韻情報の伝達能力を正確に表現す るものとして評価されるが，個々の異聴内容を嚴密に 示すものではない.このため, 富澤”の荷重べクトルに よる異聴評価法にならい, 理論上計算される周波数帯 域を，担当電極対に置き換えて，16例の平均值と標準

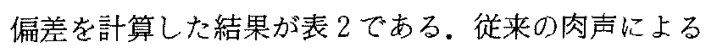
母音聴取率では, 異聴傾向は推測できるものの, 具体 


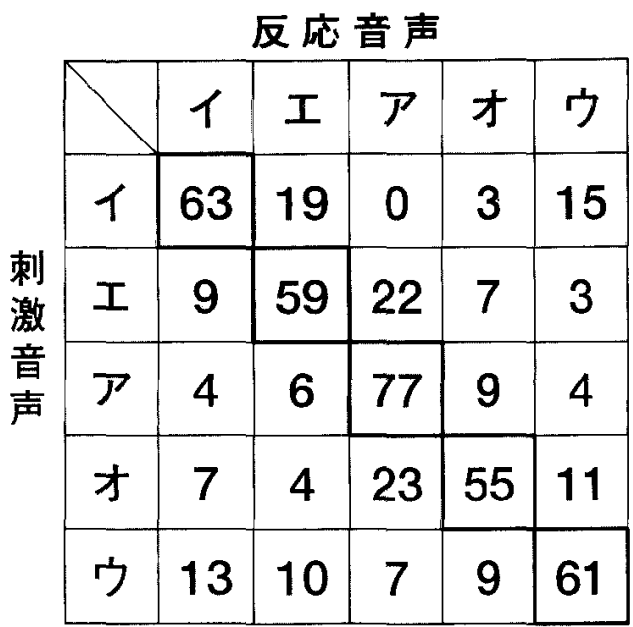

図 5 合成母音の異聴表

人工内耳患者 16 名の合成母音検査の統計

で，゚ーセント表示である。

的に電極間距離との関係は不明であった。理論上では， 電極位置が異なるほど異聴が減少すると考えられてい たことが，今回合成母音検査を施行することで，具体 的に，電極を何本離せば異聴がどれだけ減少するかと いうことを，証明することができた。ただし，これは， 挿入電極数ごとに分類して評価することがより望まし いが, 現在, 日本で人工内耳患者がまだ200例程度であ り，今後さらにデー夕を集積する必要があるものと考

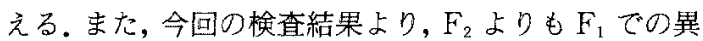
聴がより少ない傾向が発見されたが，この理由として 以下の推測を行った。蝸牛内に晾ける周波数分布は均 一ではなく，基底回転奇りのほうでは高音ふら密に配 列し，頂回転に行くに従い低音が疎に分布している. 近年では，蝸牛で鋭い周波数弁別が可能であると言わ れて和り ${ }^{10111) 12)}$,この解剖学的理由により, 人工内耳で は, 先端部により近い $\mathrm{F}_{1}$ の方が，刺激電極の移動によ る周波数弁別が, $\mathrm{F}_{2}$ に比べより容易である可能性が考 えられる。つまり，電極は面回転にできる限り近づけ るように深く挿入し，22本すべて挿入することが，術 後の聴取能を良くする方法であると考えられる。また， 22 チャンネル人工内耳で， $F_{1}+F_{2}$ において 6 電極以 上離すことがでれれば，5\%以下の低い異聴率が得ら れることが証明された。

実際に人工内耳患者16名に実施した，合成母音検査 による異聴表を図 5 に示す（合成母音検查表の太線部 の95\%信頼区間のみ使用).これは16例についての統計

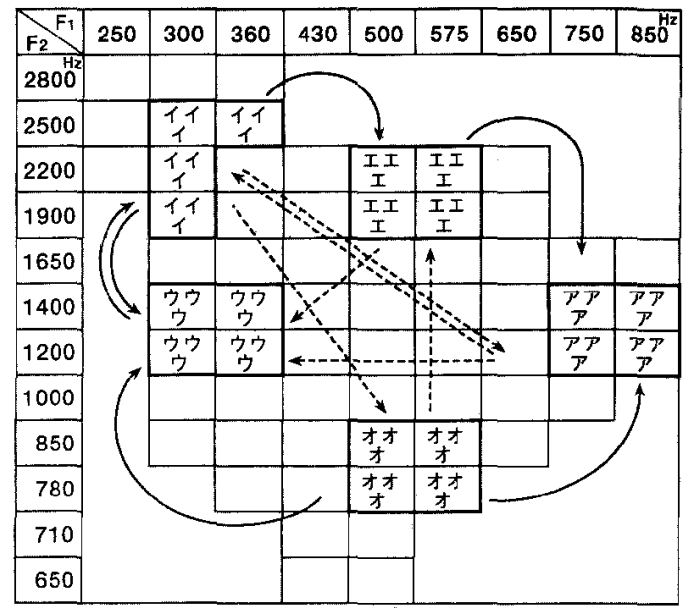

図 6 合成母音検查の $\mathrm{F}_{1}-\mathrm{F}_{2}$ パターンにおけ る異聴傾向

実線の矢印は $10 \%$ 以上の異恥を示す，点 線の矢印は $5 \%$ 以下の異聴を示す。

であり，パーセントで表示されている．10\%以上の異 聴を示したのは才 $\rightarrow$ ア $(23 \%), エ \rightarrow ア(22 \%), 1 \rightarrow$ 工 $(19 \%) ， イ \rightarrow ウ(15 \%) ，$ ウイ $(13 \%)$, オウ (11 \%)であった。逆に，5\%以下の低い異聴を示したの はイ $\rightarrow$ ア $(0 \%) ， イ \rightarrow 才(3 \%) ， エ \rightarrow ウ(3 \%) ， ア$

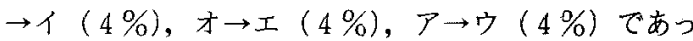
た. 以前舩坂 ${ }^{13)}$ は, 肉声による母音の暴聴表を作製し， $10 \%$ 以上の異聴を示したのがオーア $(16 \%), エ \rightarrow イ(13$

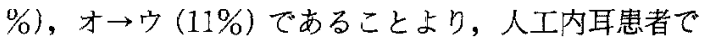
の母音認識には， $\mathrm{F}_{1} ， \mathrm{~F}_{2}$ の周波数比，または $\mathrm{F}_{2}$ の周 波数が重要であり，また，暴聴はいわば一方向で，例

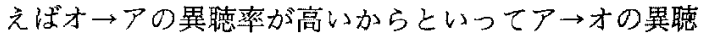
が必ずしも高くならないと報告した。今回我々の結果 でも，オーアの異聴が $23 \%$ と最も多く, $\mathrm{F}_{1}, \mathrm{~F}_{2}$ の周波 数比が近い場合（オアアでは，周波数比怯オで1.52， アで1.63）には，やはり異聴が起こりやすく，異聴は 一方向であることが証明された．また， $\mathrm{F}_{2}$ に関してオ $\rightarrow$ エ゙の異㯖は少ないが，イウ，ウーイでの異聴が

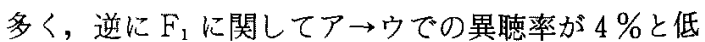
く, $\mathrm{F}_{1}$ の周波数も母音の認識には非常に重要であるこ とが示された。今回の結果を総合すると，合成母音検 查の $\mathrm{F}_{1}-\mathrm{F}_{2}$ パターンにおいて，隣りあった母音間の 異聴が多く，対角線上での異聴が少ないことが示され た(図 6)。ただしこれらのデー夕は，オーストラリア 製 22 チンンネ人工内耳を使用した場合であり，他の マルチチャンネルを使用した場合には，当然異なる結 
果が得られるものと考える. 今後, 数種類の人工内耳 が臨床応用された場合, 合成母音検查が機種の評価法 としても利用できるものと考える。

\section{5. まと め}

人工内耳患者16名に合成母音検查を行い，以下のこ とが分かった。

（1）人工内耳患者の母音聴取能を情報伝送量加ら桱 討した結果，挿入電極数が関与している可能性が示唆 された。

（2）刺激電極が異なるほど，異聴率は低くなり，さ らに $\mathrm{F}_{2}$ より $\mathrm{F}_{1}$ (低音成分)での異聴がより少ない傾向 が認められた。

電極はできる限り深く挿入し，また22本すべて挿入 することが望ましいと結論された。

\section{文献}

1) Wever EG: The width of the basilar membrane in man. Ann Otol Rhinol Larygol 47: 37-47, 1938.

2）富澤正雄：感音性難聴における合成母音の識別に関す る研究. Audiology Japan 14: 202-229, 1971.

3）舩坂宗太郎，林原成子，高橋 整，湯川久美子, 初鹿 信一: 22 Channel Cochlear Implant 患者の言語聴取 能. 日耳鼻 $90: 995-1003 ， 1987$.

4）船坂宗太郎, 高橋 整, 湯川久美子, 城間将江, 熊川 孝三: 22 channel cochlear implant 患者の語音聴取能 とその生理学的考察. 耳堠頭頸 $60: 283-289,1988$.

5）船坂宗太郎，本多清志，初鹿信一，湯川久美子，城間 将江：22チャンネル人工内耳患者の音声・言語聴取の 実際。耳譺頭頸 62：483-488， 1990 。

6）斎滕啓光：脳幹反応を指槽とした蝸牛電気刺激に関す
る実験的研筑- Cochlear Implant $の$ 基䃈实験一、

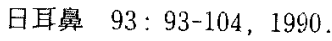

7）佐藤恒正，伊藤真郎，野呂久公: 頭蓋内疾患と語穴聴 力. Reprinted from Audiology Japan 20:334-347, 1977.

8）城間将汇，本多清志，河野 澋，船坂宗太郎，熊川萃三 ：人工内耳装用者の語音聴取能に影響を及佂す要因。 音声言語医学 $32: 371-377 、 1991$.

9) Shiroma M, Honda K, Yamanaka N et al : Factors cotributing to phoneme recognition ability of users of the 22-channel cochlear implant system. Ann Oto Rhinol Larygol 101: 32-37, 1992.

10) Sachs MB, Young BD: Effect of nonlinearities on speech encoding in the auditory nerve. $\mathrm{J}$ Acoust Soc Am 68: 858-875, 1980

11) Tong YC, Clark GM, Blamey PJ et al: Psychophysical studies for two multiple-channel cochlear implant patients. J Acoust Soc Am 71 : 153-160, 1982.

12) Dallos $\mathrm{P}$ : The active cochler. J Neurosci $12: 4575$ -4585, 1992.

13）舩坂宗太郎：人工内耳一罷回復八の貢献一. 第93回 日本耳鼻咽䓡科学会総会・学術講演会宿題報告：4647,1992 .

本論文の要旨仿第38回日本聴覚医学会において講演し た。

(1994年 4 月28日受稿 1994 年 6 月 2 日受理)

別刷請求先 $\bar{\top} 160$ 東京都新宿区西新宿6-7-1 東京医科大学耳鼻咽喉科学教室 斎藤啓光 